\title{
Evaluation of Two Estrus Synchronization Protocols in Dairy Cattle at North Shoa Zone Ethiopia
}

\author{
Yeshimebet $C^{1^{*}}$, Tesfaye $Z^{2}$, Hulunim $G^{3}$, Lina $G^{3}$, Getachew $K^{3}$, Chekol $D^{2}$, Amare $B^{4}$, Ayele $A^{2}$ and Yishak \\ Tsegaye $^{4}$
}

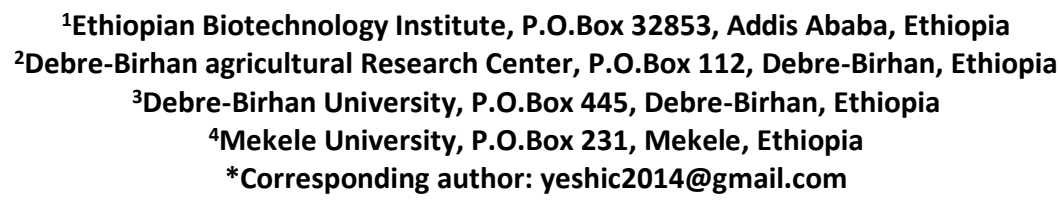

\begin{abstract}
This study was initiated to change the hesitation of the farmer (Ethiopian smallholder) on the effectiveness of estrus synchronization under their livestock management system. Non-pregnant animals with normal reproductive tract and that fulfilled the preconditions for estrus synchronization were considered for treatment and assigned into two synchronization protocols (single PGF2 $\alpha$ injection; and double PGF2 $\alpha$ injection). Among 94 (27 heifer and 67 cows) synchronized cows using one and two injections of PGF2 $\alpha$ protocols 26 heifers and 63 cows both exhibited (89/94.7\%) estrus by visual observation and rectal palpation the remaining 5 (5.3\%) did not illustrate heat. The overall pregnancy following Al was $59.6 \%$ with overall birth $94.3 \%$. High pregnancy was obtained in the double injection of PGF2 $\alpha$ treatment group (63.1 \%) than animals treated with one shot protocol $55.8 \%$ there were statistically significant difference between treatments $(p<0.05)$. Moreover most of the animals come to estrus greater than $96 \mathrm{hrs}$. There was also significant difference between technicians on detecting the $\mathrm{CL}$ and conception. The estrus response, conception rate, pregnancy rate and calving rate was higher in both protocols so producers or farmers can use either the two protocols to achieve remarkable result but tight follow-up and more resources are need to be exploited at farmer level.
\end{abstract}

Kev words: PGF2 $\alpha$, estrus, synchronization, pregnancy.

Abstrak. Penelitian dilaksanakan untuk mengubah keengganan peternak skala kecil di Ethiopia menggunakan sinkronisasi estrus dalam manajemen ternak. Pemilihan betina non bunting didasarkan pada kondisi organ reproduksi yang normal. Perlakuan menggunakan dua protocol yakni satu kali dan dua kali penyuntikan PGF2 $\alpha$. Diantara 94 sapi betina (27 dara dan 67 induk) yang disinkronisasi estrusnya menggunakan satu kali dan dua kali penyuntikan PGF2 $\alpha, 26$ dara dan 63 induk memunculkan ciri-ciri estrus $(89 / 94,7 \%)$ yang dapat diamati secara visual dan palpasi rektal, sedangkan 5 sapi lainnya $(5,3 \%)$ tidak menunjukkan gejala estrus. Persentase kebuntingan yang diperoleh dari hasil IB sebesar 59,6\% dengan angka kelahiran 94,3\%. Kebuntingan tinggi ditemui pada ternak yang memperoleh penyuntikan PGF2 $\alpha$ dua kali $(63,1 \%)$ dibandingkan dengan ternak yang memperoleh penyuntikan hanya satu kali $(55,8 \%)$. Secara statistik, perbedaan tersebut signifikan $(p<0,05)$. Lebih lanjut, sebagian besar ternak mengalami estrus lebih dari 96 jam. Perbedaan signifikan juga dijumpai pada kemampuan teknisi dalam mendeteksi CL dan kebuntungan. Respon estrus, tingkat konsepsi, tingkat kebuntingan, dan tingkat kelahiran lebih tinggi pada kedua protokol sehingga peternak dapat menggunakan kedua protocol tersebut untuk memperoleh hasil yang baik namun harus segera dibarengi dengan penggunaan sumber daya yang lebih memadai pada tingkat peternak.

Kata kunci: PGF2 $\alpha$, estrus, sinkronisasi, kebuntingan

\section{Introduction}

Animal breeding and reproduction are at the top of the animal production pyramid (Ahlawat et al, 2015) and is a key for successful dairy farming (Roelofsl and Kooij, 2015). Fertility remains as an important factor for the production and profitability in dairy herds. Dairy sector development in smallholder farming systems is one of the key strategic important areas for addressing food security and improved livelihood in developing countries particularly in Ethiopia. In order to improve the low productivity of dairy cattle, selection of the most promising breeds and cross breeding of these indigenous breeds with highly productive exotic cattle have been considered a practical solution (Tadesse, 2010). Fertility in farm 
animals may be expected towards of estrus synchronization (Islam, 2011) which is one of the alternatives for the control and manipulation of reproduction (Ahlawat et al, 2015).

Estrus synchronization can be a useful tool in the reproductive management of a cow herd but it needs proper levels of nutrition, body condition and health with skilled estrus detection and Al technician. However, inadequacy in any of these areas can spell disaster for an estrous synchronization program. Improvements in facilities and management may be necessary before implementing an estrous synchronization program and treatments should be initiated only when cows are at least 50 days postpartum (Cushman et al., 2007, Troxel, 2012, Lamb, 2013, Gizaw et al, 2016).

Availability, regularity and effectiveness/ efficiency of the service are below expectation of farmers (Personal communication). It is obvious that the farmers evaluate the technology based solely on successful breeding leading to calf production. With healthy, cyclic heifers in good body condition, first service conception rates with skilled Al technicians may approach $75 \%$. However, the more accurate estimation is 50 to $55 \%$ (Troxel, 2012, Gizaw et al, 2016). Recently, the government of Ethiopia and other NGOs (non-governmental organizations) are making various efforts to improve dairy productivity through breed improvement programs using estrus synchronization and mass artificial insemination (Birhanemeskel, 2014).Therefore, Based on the result of farmer perception, it was essential to assess the status of previous mass synchronization program implemented at North Shoa Ethiopia milk shed areas and evaluate different estrus synchronization protocol.

\section{Materials and Methods}

This study was conducted at North Shoa zone Basona Werana and Angolela Tera milk shed districts to confirm to the farmers the productivity of estrus synchronization technology.

\section{Questioner survey}

Semi-structured questionnaire was administered for 140 respondents to collect data on perception of the farmers who were participated on previous mass synchronization programs, village development agents, zonal and districts agriculture office animal health and production employers were included in the assessment. The interview also include if the estrus synchronization were practical or not, which hormone have been used, amount and frequency of hormone given to the cow, period of last birth, how were the follow-up to detect estrous synchronization, the interval between the last treatment (hormone administration) and Artificial Insemination, the response of Al in terms of productivity (becoming pregnant or not).

\section{Study animals}

From a total of 134 animals presented by farmers the experiment included (selected) only 94 cows ( 27 heifer and 67 cows) that fulfilled the preconditions for estrus synchronization with different parties and greater than 60 days post-partum. All animals were evaluated for BCS (Body Condition Scoring) using 1 to 5 BCS system (1, a very thin cow with no fat reserves, to 5 , a severely over conditioned, ideal condition scores fall in the range of 3.0-4.0). Animals scored $\geq 2.5 \mathrm{BCS}$ were examined for general health, performance and abnormalities of reproductive tracts to confirm the reproductive stage, presence of mature corpus luteum and whether they were free from any reproductive tract abnormalities and pregnancy test prior to hormone administration by rectal palpation. 


\section{Experimental Design}

Healthy, animals were considered for treatment \& assigned into two synchronization protocols. Experimental animals were randomly assigned to one of the two treatment protocols ( $1=$ single PGF $2 \alpha$ injection; and $2=$ double PGF $2 \alpha$ injection).

\section{One-shot PGF2 $\alpha$ protocol}

On rectal palpation and physical observation, cyclic females that fulfilled the preconditions (healthy, good performance, presence of mature corpus luteum free from any reproductive tract abnormalities and pregnancy) were received single injection of $5 \mathrm{ml}$ lutalyse $(33.5 \mathrm{mg}$ of dinoprost tromethamine per $5 \mathrm{ml}$ of solution, equivalent to $25 \mathrm{mg}$ of PGF2 $\alpha$; Lutalyse $^{\circledR}$; Pharmacia and Upjohn Company, Pfizer, New York, USA) intramuscularly (IM) on Day 0 (fig 1 ), (protocol $1, n=48$ ), and then all females were inseminated exhibiting estrus. Animals were observed for any external symptoms of estrus (for example, clear vaginal discharge, mounting other cattle, allowing other cattle to mount them, and other related signs). All animals were observed four times a day morning, noon, early evening, and mid night.

\section{PGF2 $\alpha$}

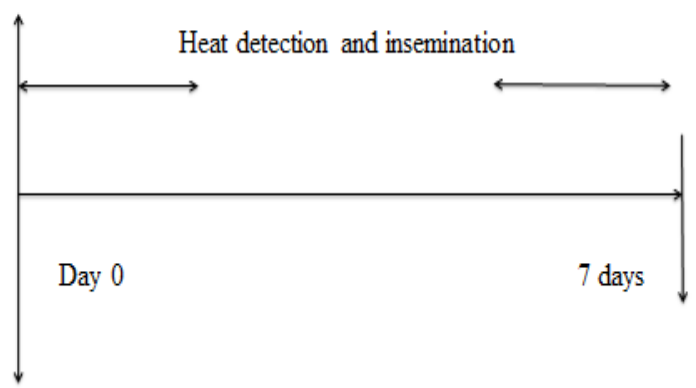

Figure 1. Protocol one

\section{Two-shot PGF2 $\alpha$ protocol}

This method of synchronization with PGF $2 \alpha$ was to inject those animals NOT come into heat in the first injection (11 days after first injection). Animals not detected with estrus after the first injection were examined for the presence of corpus luteum and they were allocated in this protocol $2(n=46)$ to be injected with $5 \mathrm{ml} \mathrm{PGF2} \alpha$ (lutalyse) on Day 0 , which was followed by re-injection of $5 \mathrm{ml}$ dose of lutalyse (PGF2 $\alpha$ ) IM 11 days after (Zeuh et al., 2014). Animals were observed for estrus expression after 24 hours of the second injection of PGF $2 \alpha$ and bred 8-12hrs post heat confirmation.

The following Figure 2 illustrates the double dose injection and time schedule of synchronization protocols. In both treatment groups, animals were inseminated either following visual observation of heat signs and rectal palpation and clean up time of Al were also used based on the rectal palpation after the second injection of PGF2 $\alpha$.

$1^{\text {st }} \mathrm{PGF} 2 \alpha$

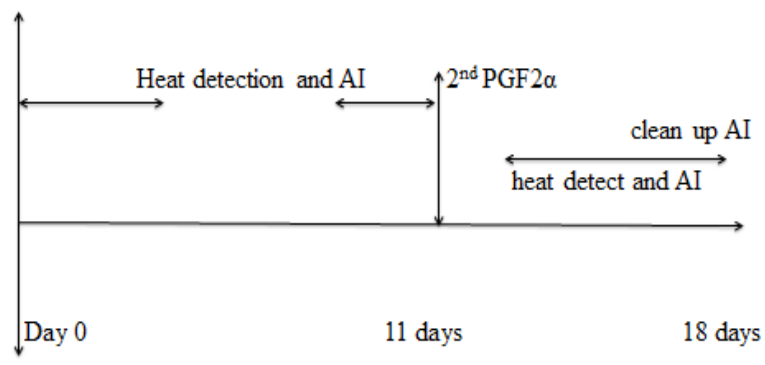

Figure 2. Protocol two

\section{Estrus response detection of cows and heifers}

Cows and heifers which did not exhibit oestrus after hormonal treatment were considered as anestrus in each treatment group. Heat response and the time interval to exhibit estrus of each treated cows and heifers were recorded by observing the estrus signs at $24,48,72,96,120$, and $>120$ hours. Those cows and heifer that expressed estrus after PGF2 $\alpha$ injection in the two treatments were artificially inseminated using frozen semen.

Conception rate were calculated as the number of animals conceive from that are exhibit estrous and inseminated. In the experiment conception rate were recorded as non-return to 
heat after one cycle from the insemination time and Pregnancy diagnosis was conduct by rectal palpation by experienced technicians and using ultrasound at 90 days after Al.

\section{Efficiency of Artificial Insemination technicians}

The Al technicians checked the presence of $\mathrm{CL}$ through rectal palpation to screen the lactating cows for synchronization. Then to perform comparative evaluation of the efficiency of Al technician's heat response and pregnancy diagnosis and birth data was collected from all inseminated cows and heifers by technicians.

\section{Statistical analysis}

To analyze the questioner survey and experimental data descriptive analysis was used (percentages, frequency distribution, mean and standard deviation). Reproductive performance analysis was also be conducted by using Generalized Linear Models (GLM) of SPSS version 20 . The level of significance was set at $\alpha<0.05$.

\section{Results and Discussion}

\section{Questioner survey result}

The questioner survey result showed that from 140 respondents 112 were males and 28 were females. Most of the respondents can read and write. In the mass synchronization programs organized by the regional government participant were nominated by agricultural bureau of each district. A respondent who was participated in mass synchronization program reflected that there were selection criteria like pregnancy test and health status for animals to be included in the program. During synchronization program held in years 2014 and 2015 from a total of 1700 synchronized and inseminated cows at 72 hours (fixed time) after synchronization 24 (1.4\%) was pregnant according the respondent.

\section{Experimental results}

\section{Effect frequency of Prostaglandin injection on Estrus expression Rate}

Out of a total 94 cows (27 heifer and 67 cows) estrus were detected on 26 heifers and 63 cows $(89 / 94.7 \%)$ by visual observation and rectal palpation the remaining $5(5.3 \%)$ did not exhibit heat sign. From a total 89 (94.7 \%) cows that showed estrus 67 (75.3\%) were active heat with clear and watery mucus discharge, hyperemic and swollen vulva, turgid uterus and cervix. While $22(24.7 \%)$ were silent heat showing highly hyperemic and turgid uterus and cervix.

The estrus response that received double injection was 2.43 times more likely compared with animals that received single injection (OR=2.43; 95\% Cl: 2.086- 2.838) and this difference was statistically significant. Higher estrus response and pregnancy rate were observed at 96,120 and 72 hours duration of heat manifestation (Figure 3).

\section{Variation in pregnancy and birth due to treatment breed and parity}

The overall pregnancy from the two treatments was $59.6 \%(\mathrm{~N}=53)$ and the overall birth were $94.3 \%(\mathrm{~N}=50)$. More pregnancy indicated from two shot treatment is $63.1 \%$ $(\mathrm{N}=29)$ than animals treated with one shot protocol $50 \%(\mathrm{~N}=24)$ there were statistically significant difference between treatments $(p<$ 0.05 ). Heifers show higher pregnancy and birth rates than cows (table 1 ). Cows with 1-3 parties showed higher (25/39.7\%) pregnancy and birth rates than cows with $\geq 4$ parity that gave $19.1 \%$ pregnancy and birth rate.

Variation in pregnancy rate due to production system, body condition, Al technician, bull Id

Animals reared in intensive system shows higher pregnancy than extensively kept animals $13(62 \%)$ and $40(55.6 \%)$ respectively (table 2 ). There was great variation in terms of skill of technicians from different working place with 
the highest degree of conception success $76.9 \%$ for T3 followed by T4 (70\%), T1 (54.6\%) and T2 (27.3\%). In terms of degree of success of conception of semen from different bulls, Bull 75283 was the Highest $83.3 \%$ followed by bull $10251,62.2 \%$, bull $10225,57.1 \%$, bull 10239 , $47.4 \%$ and bull $11327,40 \%$.
The estrus synchronization and pregnancy rate performance can be influenced also by body condition, therefore in our study area higher oestrus response and pregnancy were recorded for body condition 3 and 3.5 and the least pregnancy was recorded for 4.5 body conditioned animals (Figure 4).

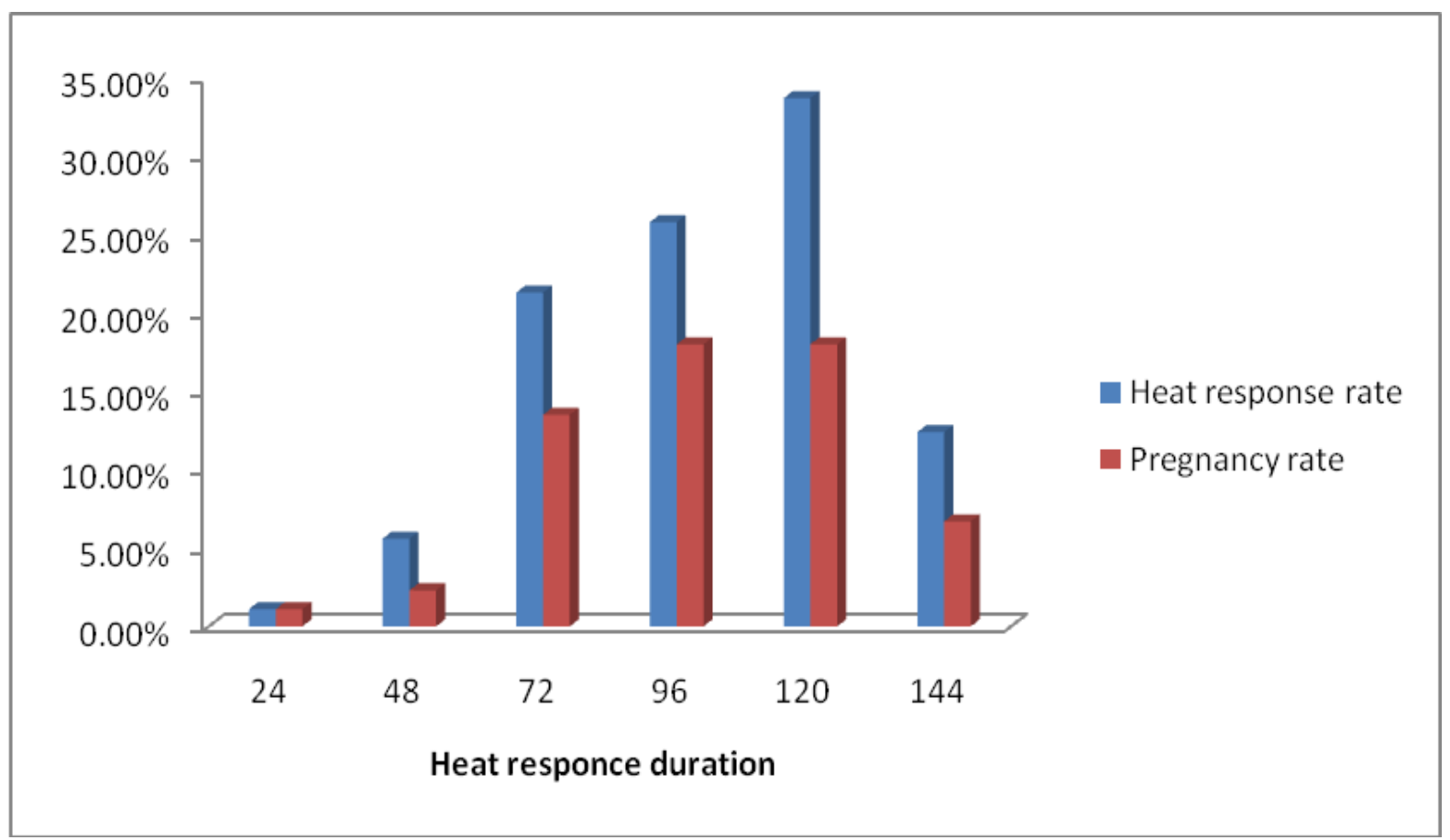

Figure. 3 Proportion of estrus response and pregnancy rate

Table 1. Pregnancy and birth rate between heifers and cows

\begin{tabular}{lllll}
\hline Pregnancy & Number of heifers & Percent & Number of cows & Percent \\
\hline Pregnancy & & & & \\
\hline Positive & 16 & 61.5 & 37 & 58.7 \\
Negative & 10 & 38.5 & 26 & 41.3 \\
Total & 26 & 100 & 63 & 100.0 \\
\hline Birth & & & & \\
\hline Calves & 16 & 100 & 34 & 81.8 \\
Abortion & 0 & 0 & 3 & 100.0 \\
Total & 16 & 100 & 37 & \\
\hline
\end{tabular}


Table 2. Pregnancy rate of inseminated cows from different study areas

\begin{tabular}{|c|c|c|c|c|c|}
\hline \multirow[t]{3}{*}{ Districts } & \multirow{2}{*}{\multicolumn{2}{|c|}{$\begin{array}{l}\text { Single } \\
\text { Injection }\end{array}$}} & \multirow{2}{*}{\multicolumn{2}{|c|}{$\begin{array}{l}\text { Double } \\
\text { Injection }\end{array}$}} & \multirow{3}{*}{$\begin{array}{l}\text { Overall } \\
\text { pregnancy }\end{array}$} \\
\hline & & & & & \\
\hline & $\begin{array}{l}\text { Inseminated } \\
\text { cows }\end{array}$ & PD positive & $\begin{array}{l}\text { Inseminated } \\
\text { cows }\end{array}$ & PD positive & \\
\hline Cheki & 22 & $11(50 \%)$ & 25 & $15(60 \%)$ & $26(59.1 \%)$ \\
\hline Baso & 15 & $8(53.3 \%)$ & 10 & $6(60 \%)$ & $14(58.3 \%)$ \\
\hline Privet farms & 11 & $6(54.6 \%)$ & 11 & $7(63.6 \%)$ & $13(62 \%)$ \\
\hline Total & 48 & 24 & 46 & 29 & $53(59.6 \%)$ \\
\hline
\end{tabular}

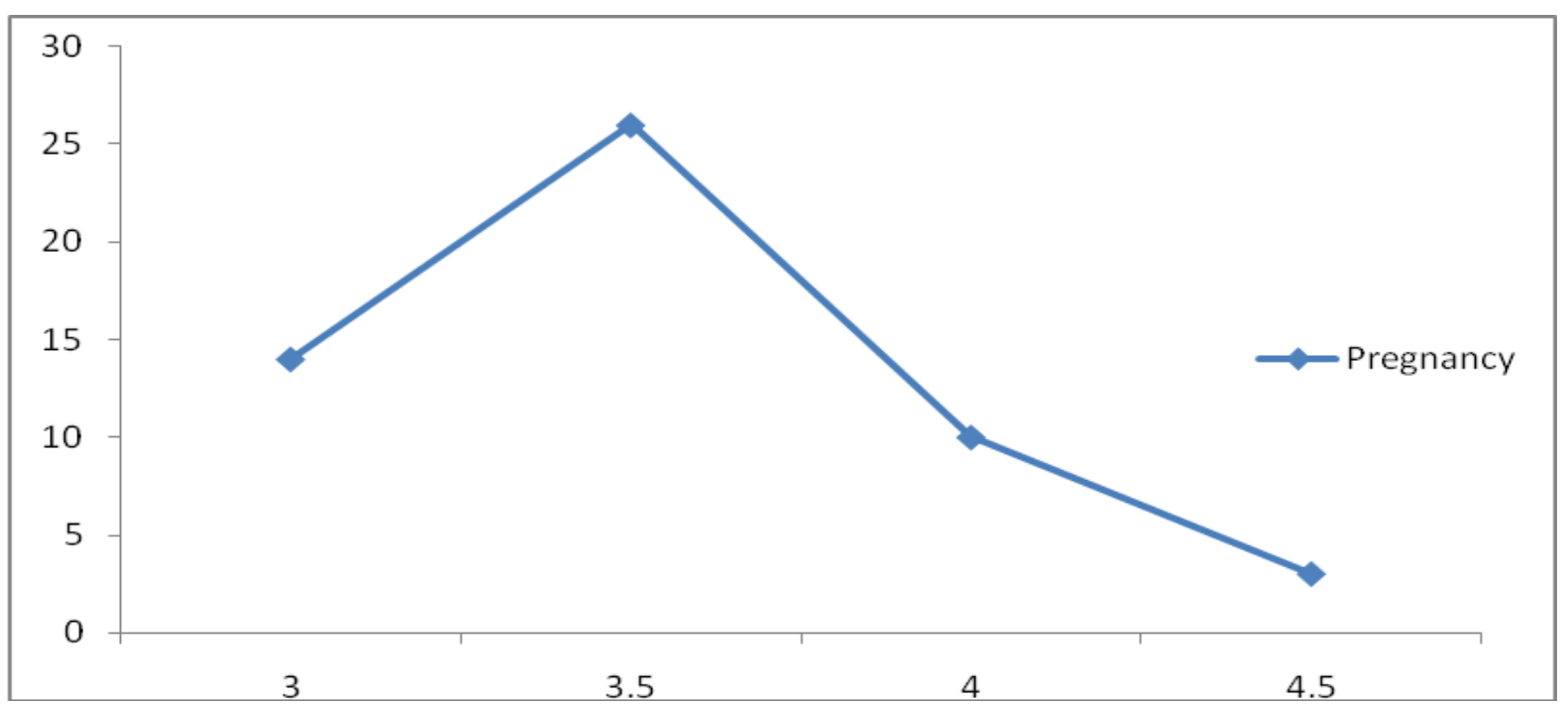

Figure 4. Effect of body condition on pregnancy rate

Within 14 days $89(94.7 \%)$ cows were population of the study area $14(0.2 \%)$ cows inseminated with estrus synchronization and 53 showed heat and they were inseminated during (59.6\%) were pregnant whereas by natural heat our study time (46 days) and 9 of them were expression from of a total 8097 cattle pregnant (Figure 5).

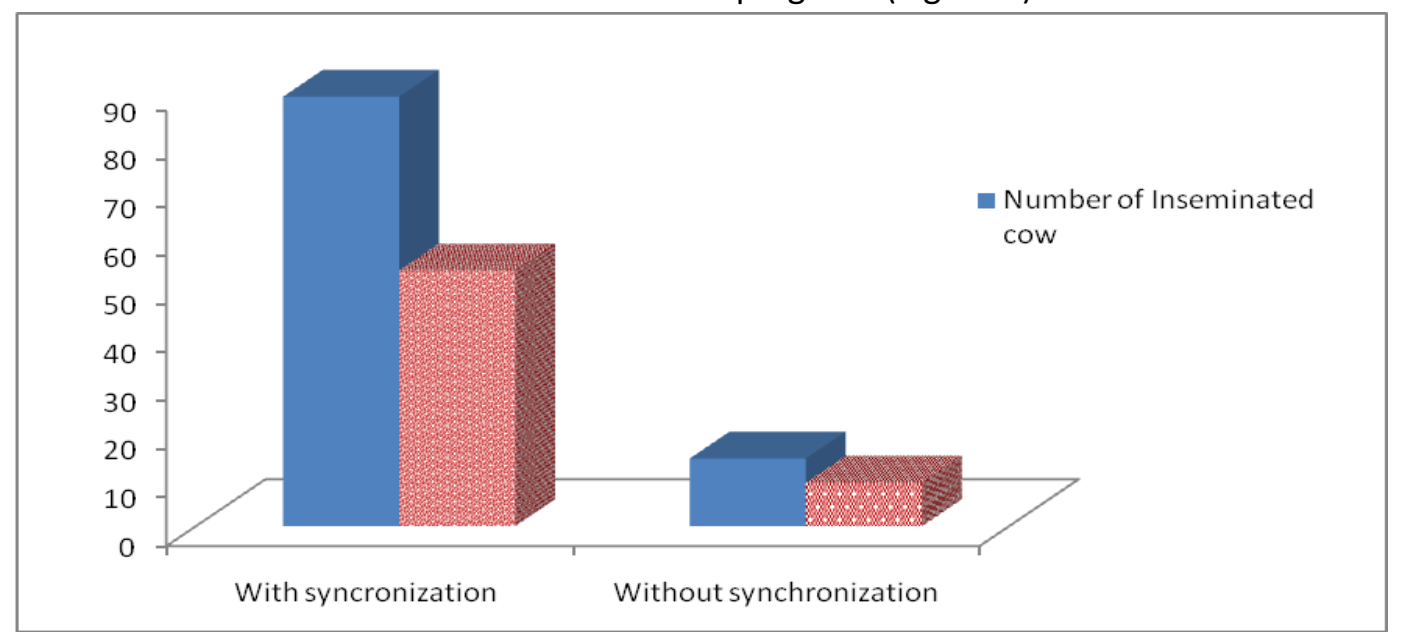

Figure. 5 Heat and pregnancy rate with and without synchronization 


\section{Discussion}

According to the result obtained by respondents $(140$ small holders, village development agents, zonal and districts agriculture office animal health and production employers) from a total of 1700 animals synchronized and inseminated $24(1.4 \%)$ was pregnant. This is much lower than our result (53/ 59.6\%). This gap may come up due the usage of fixed time insemination at 72 hours post PGF $2 \alpha$ administration, selection of animals for the service, semen and technical limitations, problem of timely insemination of animals drives to the negatives perception to synchronization and poor pregnancy result which is in agreement with the study conducted on farmer's perception by Legesse, (2015).

The result of this study showed $94.7 \%$ estrus response rate higher than $75.9 \%$ reported by Small et al, (2001). The estrus response rate from single shot injection of this study was $89.6 \%$ in line with $76.47 \%$ reported by Zeuh et al., (2014). With healthy, cyclic heifers in good body condition, first service conception rates with skilled Al technicians may approach 75\%, our study found $66.3 \%$ overall conception rate comparative with the conception rates reported by Gugsa (2015) $62.2 \%$ and slightly higher than Binessagne, (2015) report (52.9\%).

The highest pregnancy were achieved in animals inseminated within 7-12hrs after detected in estrus which is closely similar with the findings of Legesse, (2015) reported $>10$ $15 \mathrm{hrs}$ and it is greatly different from the findings of Jemal, (2016) the highest pregnancy was achieved in animals inseminated within 1020 hrs. While more recent experiments indicated the optimum time for Al was 4-12 h after onset of estrus in dairy cattle (Dorseya et al, 2011).

\section{Conclusions}

The reason of the high unproductiveness of mass synchronization was the use fixed time insemination, the lack skilled $\mathrm{CL}$ and estrus detectors Al technicians and body condition scoring problem. The overall estrus response, conception rate, pregnancy rate and calving rate from both protocols was higher so producers or farmers can use either of the two protocols to achieve remarkable result but tight follow-ups, time and more resources are need to be implement. More over most of the animals come to estrus greater than 96hrs. There was also significant effect of skill of technicians on $\mathrm{CL}$, conception and pregnancy detection.

The government should set-up mass synchronization program by changing previous approach. At least one Al technician should be appointed for each tabia (divisions of districts) to be successful in the $\mathrm{Al}$ and synchronization program with continuous Skill up-grading trainings for technicians. Two or one shot protocol can be implemented with detection of estrus and with great care in all aspects that may affect the success of the program. In the future researches should be done on the effects of thawing temperature and time on conception rate and on economic impact of mass synchronization program.

\section{Acknowledgements}

The study was financially supported by the Amhara Regional Agricultural Research Institute, Debre-Birhan Agriculture Research Center and Debre-Birhan University. The technical support of Debre-Birhan Agricultural Research Center, livestock Research Directorate and Debre-Birhan University is very much appreciated. 


\section{References}

Ahlawat, A. R., Ghodasara, S. N. Dongre, V. B. Gajbhiye, P. U. Murthy, K. S. Savaliya K. B. and Vataliya, P. H., 2015. Estrus induction and conception rate with single and double dose of PGF2 $\alpha$ in Jaffrabadi buffaloes. Asian Journal of Animal Science, 10(1): 54-57.

Binessagne, W., 2015. Assessment of Breeding Practices and Evaluation of Estrus Synchronization and Mass Insemination Technique in Dairy Cattle in West Shoa Zone. Msc Thesis, Haramaya University, Haramaya, Ethiopia.

Birhanemeskel, A., 2014. Evaluation of the Reproductive Performance of Crossbred ( $\mathrm{Hf} \mathrm{X}$ Zebu) Dairy Cows and Artificial Insemination Service Efficiency in and Around Adigrat, North Ethiopia. Msc Thesis, Haromaya University, Ethiopia.

Cushman, R. S., Echternkamp, M. Allan, and Freetly, H., 2007. Identification of indicator traits of fertility in the postpartum beef cow. Biology of Reproduction (Spec. Iss.):187. (Abstr. 443).

Dorseya, B. R., Kasimanickamb, R. Whittierb ,W. D. Nebelc, R. L. Wahlberga, M. L. Halla, J. B., 2011. Effect of time from estrus to Al on pregnancy rates in estrous synchronized beef heifers. Animal Reproduction Science 127, 1- 6.

Gizaw, S., Tesfaye, Y. Mekuriaw, Z. Tadesse, M. Hoekstra, D. Gebremedhin, B. and Tegegne, A., 2016. Oestrus synchronization for accelerated delivery of improved dairy genetics in Ethiopia: Results from action research and development interventions. LIVES Working Paper 12. Nairobi, Kenya: International Livestock Research Institute (ILRI).

Gugssa, T., 2015. Effects of Prostaglandin Administration Frequency, Artificial Insemination Timing and Breed on Fertility of Dairy Cows and Heifers in Eastern Zone, of Tigray Region, Ethiopia. MSc Thesis, Mekelle University.

Islam, R., 2011. Synchronization of Estrus in Cattle: A Review. Veterinary World. 4(3):136-141.

Jemal, H., Lemma, A. and Bekana, M., 2016. Assessment of the Reproductive Performance of
Dairy Cows in Smallholder Dairy Farms Using Artificial Insemination. Livestock Research for Rural Development, 28(81). http://www.Irrd.org//rrd28/5/jema28081.html. Lamb, G. C., 2013. Control of Estrus in Cows. Proceedings of Applied Reproductive Strategies in Beef Cattle. Staunton, VA.

Legesse, D., 2015. Assessment of breeding practices and evaluation of mass estrus synchronization of dairy cattle in sidama zone, southern Ethiopia. MSc thesis, Hawassa University, Hawassa, Ethiopia.

Perry, G., 2004. The Bovine Estrous Cycle. South Dakota State University-Cooperative Extension Service-USDA, FS921A:

http://agbiopubs.sdstate.edu/articles/FS921A.pd f

Roelofs, J. B. and Kooij, E.V., 2015. Estrus detection tools and their applicability in cattle: recent and perspectival situation. Animal Reproduction, 12(3), p.498-504.

Senger, P. L, 2005. Pathway to Pregnancy and Parturition. $2^{\text {nd }}$ revised ed. PP: 144-188.

Small, J. A., Ambrose, D. J. McCaughey, W. P. Ward, D. R. Sutherland, W. D. Glover, N.D. and Rajamahendran, R., 2001. The effects of gonadotrophin releasing hormone in prostaglandin F2a-based timed insemination programs for beef cattle. Canadian journal of animal science, 81: 335-343.

Tadesse, A. S., 2010. The Status and Constraints of Artificial Insemination in Cattle in the Three Selected Districts of Western Gojjam Zone of Amhara Region, Ethiopia. MSc Thesis, Bahrdar University, Bahrdar,, Ethiopia.

Troxel, T. R., 2012. Synchronization of Estrus in Cattle. University of Arkansas. Beef Reproduction Task Force, MP383-PD-6-13RV

Zeuh, V., Youssouf, M. Dingamtar, N. and Dezoumbe, D., 2014. Evaluation of two methods of estrus synchronization of cattle in Chad. Open Journal of Animal Sciences, 4,

13-17. 